\title{
Understanding the relationship between intel- lectual capital and organizational performance: the role of e-HRM and performance pay
}

\author{
Alessandra Lazazzara ${ }^{1}$, Edoardo Della Torre ${ }^{2}$, Raoul C.D. Nacamulli ${ }^{3}$ \\ 1 Department of Social and Political Sciences, University of Milan, Milan, Italy. \\ alessandra.lazazzara@unimi.it \\ 2 Department of Management, Economics and Quantitative Methods, University of Bergamo, \\ Bergamo, Italy \\ edoardo.dellatorre@unibg.it \\ 3 Department of Educational Human Sciences, University of Milano-Bicocca, Milan, Italy \\ raoul.nacamulli@unimib.it

\begin{abstract}
While the bulk of the literature on intellectual capital focuses on its role as a source of competitive advantage, fewer studies have analyzed the mechanisms through which human, social and organizational capital translate into high organizational performance. Drawing on the resource-based view and intellectual capital research, this paper aims to analyze how the adoption of eHRM tools and performance pay affects the contribution of intellectual capital to organizational performance. The analysis performed on a sample of 168 Italian large organizations from the CRANET survey (2015) shows that, while intellectual capital is positively related to organizational performance, such relationship is weakened in presence of high levels of e-HRM. Moreover, in contexts of high intellectual capital, the combined presence of high level of performance pay and e-HRM nullifies the positive impact of intellectual capital on performance, whereas in contexts of low intellectual capital they lead to higher performance. Implications of these findings for theory and practice are discussed.
\end{abstract}

Keywords: Intellectual capital, E-HRM, Performance pay, Organizational performance, Resource-based view, Italy.

\section{$1 \quad$ Introduction}

In the current knowledge-based economy intellectual capital represents one of the main sources for companies success (Subramaniam \& Youndt, 2005). It can be defined as "the sum of all knowledge firms utilized for competitive advantage" (Subra- 
maniam \& Youndt, 2005, p. 451) and has been categorized into three components: a) human capital refers to knowledge, skills, and capabilities of individual employees; b) social capital involves the knowledge embedded relationships and interactions among individuals; c) organizational capital is the institutionalized knowledge stored in databases, manuals, culture, systems, structures, and processes. Adopting a resource-based perspective (Penrose, 1959; Barney, 1991), it can be argued that the three dimensions of intellectual capital (i.e., human, social and organizational capital) are often location-specific, involve tacit learning, and are socially complex and causally ambiguous (Ployhart et al., 2014; Wright et al., 2014; CIPD, 2017). The influence of intellectual capital on firms' outcomes has been widely investigated by existing literature and, although some contrasting findings emerged, it can be generally maintained that intellectual capital has a positive relationship with firms' outcomes (Crook et al., 2011; Youndt et al., 2004).

While the bulk of the literature on intellectual capital focuses on its role as a source of competitive advantage, fewer studies have analyzed the mechanisms through which human, social and organizational capital translate into high organizational performance. In this paper, we contribute to this stream of the literature by analyzing how electronic-HRM (e-HRM) and performance-pay affect the relationship between intellectual capital and firm performance. Indeed, the adoption of "integration mechanisms and contents between HRM and IT, aimed at creating value for targeted employees and managers" (Bondarouk and Ruel, 2009, p. 507) is one of the most significant changes that has characterized the HR function in the last decade. Similarly, performance-related pay has been often indicated as one of the main tools that HR managers can adopt in order to increase employees motivation and performance. Thus, a better understanding of how these practices (e-HRM and performance-pay) impact on the intellectual capital of a firm is of paramount importance for advancing the HRM field and depicting relevant implications for HR professionals.

Drawing on the resource-based view and intellectual capital research, this paper aims to analyze how the adoption of e-HRM tools and performance pay affect the contribution of intellectual capital to organizational performance. The analysis is based on 168 Italian organizations and the data come from the CRANET survey (2015). In the next section, the theoretical approach is presented and the hypotheses are developed. Then we present the empirical analysis and the results. We conclude by discussing the contribution and implications of the main findings of the study.

\section{Theoretical framework and hypotheses}

\subsection{Intellectual capital and organizational performance in the RBV perspective}

Over the last years, many researchers have applied the resource-based view (RBV) to identify the kind of resources most likely to influence competitive advantage and performance. In so doing, many have converged on companies' intellectual capital as 
one of the most universally valuable resources (see Crook et al., 2011; Spender and Grant, 1996).

According to the RBV, firms are bundles of tangible and intangible resources and capabilities which can create a competitive advantage (Barney, 1991). Indeed, RBV assumes that the primary driver of the firm's durable competitive advantage and economic performance is a collection of resources which are valuable, rare, inimitable and organized (VRIO; Barney, 1991). According to the VRIO framework resources are valuable when are a significant source of profitability; should be rare in the sense that there is a scarcity of such resources; those resources should be hard to imitate and organizations should be fully organized in order to effectively exploit them. Therefore, this perspective "explains an important route to achieving competitive advantage and corporate success in a modern economic system in which firms rely far less on homogenous factors of production such as labor and capital and much more on differentiated resources such as human expertise, organizational routines, reputation, and complex linkages with customers and suppliers" (Chinsholm \& Nielse, 2009).

More specifically, the RBV relies on two main assumptions which derive from the pioneering work of Edith Penrose (1959): resource heterogeneity and resource immobility. Resource heterogeneity refers to the idea that performance differences may be related to the heterogeneous distribution of valuable resources - such as intellectual capital - among firms. The value of such resources increases as they are bundled together to create idiosyncratic combinations which are able to solve firm-specific problems that are peculiar of the firm's unique competitive context (Penrose, 1959; Spender and Grant, 1996). Moreover, when such idiosyncratic combinations are so complex that others cannot easily duplicate or substitute for, those companies will outperform competitors lacking such resources (Barney, 1991; Peteraf, 1993).

Theoretically, a distinct branch of the RBV - the intellectual-based view - has argued that intangible assets that firms acquire, develop and accumulate over time such as knowledge, skills, and behaviors of employees may generate outperforming results and thus create value for the company (Reed et al., 2006). Therefore, intellectual capital may be seen as an intangible asset which has the potential to create value. However, such result is related to the company's capability to implement specific sets of practices which leverage intellectual capital and allow to achieve a better incremental and radical innovative performance (Donate et al., 2016; Herremans et al., 2011; Subramaniam and Youndt, 2005).

\subsection{The moderating role of e-HRM and performance pay}

The literature on e-HRM usage in organizations has been growing rapidly together with a specific interest in advantages and opportunities that such systems are expected to confer on organizations (Obeidat, 2016). However, research looking at weather eHRM is related to specific strategic outcomes such as organizational performance is lacking (Marler \& Fisher, 2013) and empirical evidence for the actual attainment of expected benefits is scarce (Parry \& Tyson, 2011).

According to Strohmeier (2007), the resource-based view may be applied as theoretical foundation explaining the relationship between e-HRM and its consequences. 
In this perspective, e-HRM can be seen as a means to obtain human resources which are valuable, rare, difficult to imitate and non-substitutable (Barney, 1991). Moreover, e-HRM may contribute to the effective management and development of these valuable resources.

Therefore, organizations characterized by a high level of intellectual capital may gain higher performance by successfully applying e-HRM because it allows a better exploiting of human resources with such strategic characteristics. It follows that the outcome of intellectual capital depends on the extent to which IT is viewed as useful and strategic by the organization. Youndt and Snell (2004) predict that (and found support for) a positive relationship between the adoption of an accessible, userfriendly and integrated information technology HR configuration and organizational capital. In this view, hard IT infrastructures and soft HR management systems both help organizations to institutionalize tacit knowledge. Thus we expect that e-HRM positively interact with intellectual capital in influencing organizational performance. In formal terms, we predict that:

H1: The adoption of an e-HRM system moderates the positive relationship between intellectual capital and organizational performance, so that the relationship is stronger at higher level of e-HRM system adoption compared to lower.

Similarly to e-HRM, an increasing number of organizations, predominantly in the private sector, embrace pay schemes linking pay to the employee or firm performance (Cohen, 2006). Organizations can implement three distinct types of pay for performance (PRP), namely individual-based performance pay, group (collective)-based performance pay and/or company-based performance pay (profit sharing and stock options) (Milkovich et al., 2011). These three forms of pay may have different logics and effects (Nyberg et al. 2018) and the debate about the effectiveness of PRP programs is not yet resolved. However, it is generally argued that PRP is beneficial to employee performance (Jemnkins et al., 1998), and that variable (bonus) pay is more effective in influencing future employee performance than permanent (merit pay) (Nyberg et al., 2016). At the organizational level, these systems would likely to ensure higher skill levels in the workforce by attracting employees who had already achieved higher performance levels from outside and by retaining the best performers within (Lazear, 2000). These incentive and sorting effects of individual PRP should, in turn, increase the level of human capital of the organization. Highly skilled employees are more likely to be motivated when their pay is linked to their performance compared to more traditional (i.e., fixed) pay systems. Moreover, when PRP is based on group or company performance, employees are more likely to share their knowledge and to support each other, thus making the relationship between social and intellectual capital and performance stronger than in traditional pay settings. Thus, we predict that:

H2: The adoption of performance-based pay moderates the positive relationship between intellectual capital and organizational performance, so that the relationship is stronger at higher level of adoption of performance-based pay compared to lower. 
Despite the positive moderating effect that e-HRM and performance pay may have on the relationship between intellectual capital and organizational performance, the situation may become more nuanced when considering the context in which they are implemented. We argue that the joint effect of e-HRM and performance pay systems depends on contextual features and more specifically on the extent of intellectual capital characterizing the organization. More specifically, these elements working together may be perceived as either an opportunity to enhance value for the organization or having the opposite effect. Herremans and colleagues (2011) found evidence that an organizational design combining technology infrastructures with results-based control system is associated with reduced perceived uncertainty. All organizations face uncertainty and reducing the amount of uncertainty associated with decisionmaking processes is one of the main organizational aims. However, uncertainty can be either positive or negative according to the context. For example, Rastogi (2003) proposed that intellectual capital is primarily deployed in environments that are dynamic or in rapid flux, so contexts in which people have to continuously foresight, assess problems, find solutions, learn and change strategies and action plans. Therefore, the very nature of intellectual capital suggests a higher degree of uncertainty as a driver to the development of intellectual capital capabilities (Herremans et al., 2011). In this perspective, since the adoption of e-HRM and performance pay directs employees' behaviors, those individuals operating in organizations characterized by high intellectual capital may perceive the reduced uncertainty due to the joint adoption of technology and results-based control systems as a threat to the development of intellectual capital capabilities thus resulting in lower performance. In formal terms, we predict that

H3: The combined influence of e-HRM and performance-based pay on the relationship between intellectual capital and organizational performance will be stronger for firms with lower level of intellectual capital.

\section{$3 \quad$ Methodology and Results}

\subsection{Sample and procedure}

This study is based on data from the CRANET survey (2015) and the sample consisted of 168 Italian organizations. The survey provides comprehensive information about the HRM practices of organizations with over 200 employees. The key informants were the participating companies' HR directors.

Thirty-four percent of these companies operated in the manufacturing sector, $42 \%$ in the services sector and $24 \%$ in the advanced service sector. Companies were mainly private $(66 \%)$ and operating on the domestic market $(54 \%)$. Fifty-two percent had over $25 \%$ highly educated workers, and on average $75 \%$ of them reported providing some degree of flexible work arrangements. Forty percent of the firms involved in the study had over 2000 employees. 


\subsection{Variables.}

Organizational performance. It is measured by four variables (Service quality, level of productivity, profitability, rate of innovation) measuring perception of performance. A principal component analysis with Varimax rotation was conducted using SPSS, to identify emergent factor solutions for organizational performance. Factorability of the correlation matrix, as assessed via the Keyser-Meyer-Olkin test $(\mathrm{KMO}=$ $.17)$ and Bartlett's test of sphericity $(\chi 2=155,832, \mathrm{df}=6, \mathrm{p}<.000)$, was supported. The analysis yielded a one-factor solution. Percentage variance explained $=59 \%$. Cronbach's $\alpha=0.76$

Intellectual capital. We used the scale developed by Youndt et al. (2004) and later used by Subramaniam and Youndt (2005) to assess HR directors' perceptions of organizational intellectual capital. After an introductory statement referring to the extent the respondent agreed with the following items describing his/her organization's intellectual capital, fourteen items on a Likert scale from 0 (total disagreement) to 4 (total agreement) measuring the three types of intellectual capital (i.e., human, social and organizational) were provided (e.g., "Our employees develop new ideas and knowledge", "Our employees share information and learn from one another", "Our organization embeds much of its knowledge and information in structures, systems, and processes"). The three scales were combined to form one single factor measuring intellectual capital as the sum of all knowledge firms utilize for competitive advantage (Nahapiet and Ghoshal, 1998; Youndt et al., 2004). Cronbach's $\alpha=0.87$.

E-HRM. For determining the amount of e-HRM adoption a set of binary categorical variables were employed. It was calculated by adding seven categorical (yes/no) questions from the CRANET questionnaire: a) Human resource information system or electronic HRM systems for HRM activities (HRIS); b) manager self-service for HRM activities (manager self-service); and c) employee self-service for HRM activities (employee self-service); d) the vacancy page on the company website as a recruitment method (e-recruitment); e) online selection tests as the selection method (eselection); f) bottom-up or top-down electronic communication (e-communication); and g) the use of computer-based packages/e-learning for career management (elearning). Therefore, e-HRM is a formative measure of e-HRM adoption with a minimum of 0 and a maximum of 7 .

Performance pay. The amount of performance pay adoption was calculated by adding a set of binary categorical variables representing different types of payment schemes. The categorical variables from the CRANET questionnaire were: a) employee share schemes; b) profit sharing; c) stock options; d) flexible benefits; e) individual performance related pay; f) bonus based on individual goals/performance; $g$ ) bonus based on team goals/performance; and h) bonus based on organizational goals/performance. Each company rated the adoption of the above payment schemes for both professionals and clericals/manuals. Therefore, performance pay is a formative measure with a minimum of 0 and a maximum of 16 .

Control variables. Organizational size is a single indicator measuring the log of the total number of employees of the organization. Organizational age is a single indicator measuring the log of years since firm's foundation. We also controlled for sector 
$(1=$ private company $0=$ not private company) and industry membership (three categories: manufacturing, services, advanced services (ref.)). We asked respondents to rate the growth of the market currently served by their organization (5-point scale ranging from 1-“Declining to a great extent" to 5-“"Growing to a great extent"). A six-point scale was adopted to measure the proportion of the workforce with a higher education/university qualification and the proportion of young employees $(1=$ " $0 \%$ ", $2=$ " $1 \%-10 \% ", 3=$ " $11 \%-25 \% ", 4=$ " $26 \%-50 \% ", 5=" 51 \%-75 \% ", 6=" 76 \%-$ $100 \% ")$.

\subsection{Analysis and Results}

We first validated the measurement model and then tested the moderation hypothesis. Numerical predictor variables were centered on the grand mean. Descriptive statistics and correlations are reported in Table 1 . The results of the hierarchical multiple regression analyses are reported in Table 2.

TABLES 1 and 2 here

In terms of main effects, results of the full model (Model 4) showed that intellectual capital and performance pay were positively and significantly related to organizational performance. With regard to the two-way interactions between performance pay and e-HRM, performance pay and intellectual capital, e-HRM and intellectual capital, results show that e-HRM has a negative impact on the relationship between intellectual capital and organizational performance, while the interaction between intellectual capital and performance-pay is non-significant. Hence, Hypothesis 1 and Hypothesis 2 were not supported by our analysis. Interestingly, results showed that the three-way interaction term was negative and significant, thus supporting Hypothesis 3. In order to better understand the pattern of the interactions, the results were plotted in Figure 1 and 2 .

FIGURES 1 and 2 here

As Figure 1 illustrates, when intellectual capital is high, low-e-HRM adoption results in better organizational performance than high e-HRM performance $(p<.01)$. Furthermore, Figure $2 \mathrm{a}$ indicates that in organizational contexts where intellectual capital is low, the relationship between performance pay and organizational performance is significantly stronger at high e-HRM levels $(\mathrm{p}<.001)$, while it is non-significant at low levels of e-HRM. Conversely, in organizational contexts where intellectual capital is high (Figure 2b), the relationship between performance pay and organizational performance is significantly stronger at low e-HRM levels $(\mathrm{p}<.001)$, while it is nonsignificant at high levels of e-HRM. 


\section{Discussion and Conclusion}

Though preliminary, the findings reported above offer interesting evidence about how e-HRM and performance pay interact with intellectual capital in influencing organizational performance. First, consistently with existing studies, we found that intellectual capital is positively related to organizational performance. This confirms that companies that want to remain competitive in modern markets should invest on the quality of their human resources by attracting high-skilled employees, developing a cooperative and supportive social context, and providing adequate organizational practices to institutionalize the existing knowledge.

Surprisingly, our findings also show that when a company combines investments in intellectual capital with the adoption of an advanced e-HRM system the positive effect of intellectual capital is reduced. This finding can be interpreted in three ways. First, it may be the case that in presence of high levels of intellectual capital an eHRM system may be perceived as a form of control rather than as a mechanism to leverage on for further developing the human, social and organizational capital. Skilled and knowledgeable employees may be less positive toward pervasive e-HRM tools as these may reduce their perception of autonomy and freedom (Stone and Lukaszewski, 2006). Second, e-HRM systems may have negative effects on some specific dimensions of intellectual capital, and specifically on social capital. Indeed, the digitalization of the workplace can also imply a reduction (or disruption) of social interactions at work (Stone and Lukaszewski, 2006), thus reducing the social capital of the organization. Given that the three dimensions of intellectual capital complement each other, the result is a reduction of the impact of intellectual capital on organizational performance. Third, it could be that e-HRM adoption is not the result of a strategic choice on the part of the HR function. Rather, e-HRM adoption could be seen by companies in our sample more as a transactional way to automate administrative HR tasks and saving costs. Therefore, understanding the broader context and the strategic intent behind e-HRM adoption is critical in order to fully explain its effect.

Concerning performance pay, the results show that it has a positive relationship with organizational performance, but the interaction with intellectual capital is nonsignificant (and negative). Thus, while PRP per se seems able to contribute to organizational performance by the incentive and sorting effects predicted by economic theories (Lazear, 2000), it also seems unable to increase the potential contribution of intellectual capital to performance. This latter effect may be explained with the increased sense of control the employee may perceive when PRP schemes are in place. Indeed, firms with a high level of intellectual capital generally rely on the creativity and innovative behaviors of their employees as a source of competitive advantage. This organizational culture contrasts with HRM practices, such as PRP, that foster employees to adopt more conservative behaviors focused on task accomplishment rather than on the exploration of a new idea. Indeed, exploiting intellectual capital through innovation and creativity requires the possibility to fail and make mistakes, which is usually not contemplated in PRP programs.

This interpretation is consistent with the findings showing that the combined effect of high levels e-HRM and high levels PRP on the relationship between intellectual capi- 
tal and organizational performance is positive in situations of low intellectual capital and is negative in situations of high intellectual capital (Figure 2). When firms do not rely on intellectual capital for competitive advantage, having pay strictly related to performance and a strong e-HRM infrastructure that increases the level clarity and transparency in performance requirements motivates employees to be productive and to increase their level of effort to reach the assigned objectives. On the contrary, when intellectual capital is high, such systems demotivate employees to fully exploit their potential. Surprisingly, Figure $2 / \mathrm{b}$ also shows that in the context of high intellectual capital when e-HRM is low, PRP has a strong positive moderating effect on the relationship with organizational performance. Consistently with our predictions (H3), this confirms that it is only the joint effect of high e-HRM, high PRP that reduces the positive impact of intellectual capital on performance.

The paper suffers from several limitations such as cross-sectional design and common-method variance. However, the results highlight important managerial implications. Indeed, the joint adoption of these two HRM tools (i.e., e-HRM and performance pay) should be carefully evaluated by managers by taking into account the role that they assign to intellectual capital as a source of competitive advantage. Moreover, our findings highlight also the risk of an excess of techno-optimism in the adoption of e-HRM and question the appropriateness of a deterministic view of e-HRM as causing organizational positive outcomes (Strohmeier, 2007) Therefore, future research could usefully explore more in-depth the contextual HRM conditions that allow (or prevent) organizations to (from) fully exploiting the performance potential of intellectual capital. More specifically, we suggest further research to better analyze how the reduction of perceived internal uncertainty impacts knowledge-intensive organizations.

\section{References}

Barney, J. (1991), "Firms resources and sustained competitive advantage", Journal of Management, Vol. 17 No. 1, pp. 99-120.

Bondarouk, T. and Ruel, H. (2009), "Electronic human resource management: challenges in the digital era", International Journal of Human Reosurce Management, Vol. 20 No. 3, pp. 505514.

Chinsholm A.M., and Nielsen K. 2009. Social capital and the resource-based view of the firm. International Studies of Management and Organization, 39(2), pp. 7-32.

CIPD (2017), Human capital theory: assesing the evidence for the value and importance of people to organizational success, Technical report, May.

Cohen, K. 2006. The pulse of the profession: 2006-2007 salary budget survey. Workspan, September: 23-26.

Crook, T.R., Todd, S.Y., Combs, J.G., Woehr, D.J. and Ketchen, D.J. (2011), "Does human capital matter? a meta-analysis of the relationship between human capital and firm performance", Journal of Applied Psychology, Vol. 96 No. 3, pp. 443-456.

Donate, M.J., Peña, I. and Sánchez de Pablo, J.D. (2016), "HRM practices for human and social capital development: effects on innovation capabilities", The International Journal of Human Resource Management, Vol. 27 No. 9, pp. 928-953. 
Haines, V.Y. \& Lafleur, G., 2008. Information Technology Usage and Human Resource Roles and Effectiveness. Human Resource Management, 47(3), pp.525-540.

Herremans, I.M., Isaac, R.G., Kline, T.J.B. and Nazari, J.A. (2011), "Intellectual Capital and Uncertainty of Knowledge: Control by Design of the Management System", Journal of Business Ethics, Vol. 98 No. 4, pp. 627-640.

Jenkins G. D.Jr., Mitra A., Gupta N., Shaw J. D. 1998. Are financial incentives related to performance? A meta-analytic review of empirical research. Journal of Applied Psychology, 83(5), pp. 777-787.

Lazear, E.P. (2000). Performance pay and productivity, American Economic Review, 90, pp.1346-1361.

Marler, J.H. \& Fisher, S.L., 2013. An Evidence-Based Review of E-HRM and Strategic Human Resource Management. Human Resource Management Review, 23(1), pp.18-36.

Milkovich, G. , Newman, J., Gerhart B. 2011. Compensation (10th ed.). Irwin: McGraw-Hill.

Nahapiet, J. and Ghoshal, S. (1998), "Social capital, intellectual capital, and the organisational advantage", Academy of Management Review, Vol. 23 No. 2, pp. 242-266.

Nyberg, A. J., Pieper, J. R., \& Trevor, C. O. 2016. Pay-for-Performance effect on future employee performance integrating psychological and economic principles toward a contingency perspective. Journal of Management, 42(7), pp. 1753-1783.

Nyberg A.J., Maltarich M.A., Abdulsalam D.D., Essman S.M., Cragun O. 2018. Collective Pay for Performance: A Cross-Disciplinary Review and Meta-Analysis. Journal of Management, 44(6), pp. 2433-2472.

Obeidat, S.M., 2016. The link between e-HRM use and HRM effectiveness: an empirical study. Personnel Review, 45(6), pp.1281-1301.

Panayotopoulou, L., Vakola, M. \& Galanaki, E., 2007. E-HR adoption and the role of HRM: evidence from Greece. Personnel Review, 36(2), pp.277-294.

Parry, E. \& Tyson, S., 2011. Desired goals and actual outcomes of e-HRM. Human Resource Management Journal, 21(3), pp.335-354.

Penrose, E.T. (1959), The Theory of the Growth of the Firm, Oxford University Press, Oxford.

Peteraf, M.A. (1993), "The cornerstones of competitive advantage: A resource-based view", Strategic Management Journal, Vol. 12, pp. 95-117.

Ployhart, R.E., Nyberg, A J., Reilly, G. and Maltarich, M.a. (2014) Human capitalis dead; long live human capital resources!, Journal of Management, 40(2): pp. 371-98.

Rastogi, P. N. (2003) The Nature and Role of IC: Rethinking the Process of Value Creation and Sustained Enterprise Growth, Journal of Intellectual Capital 4(2), 227-248

Reed, K.K., Lubatkin, M. and Srinivasan, N. (2006), "Proposing and testing an intellectual capital-based view of the firm", Journal of Management Studies, Vol. 43 No. 4, pp. 867-893.

Spender, J.C. and Grant, R.M. (1996), "Knowledge and the firm: Overview", Strategic Management Journal, Vol. 17, pp. 5-9.

Stone, D.L. and Lukaszewski, K.M. (2006), "An expanded model of the factors affecting the acceptance and effectiveness of electronic human resource management systems", Human Resource Management Review, Vol. 19 No. 2, pp. 134-143.

Strohmeier, S., 2007. Research in e-HRM: review and implications'. Human Resource Management Review, 17, pp.19-37.

Stone, D.L. \& Lukaszewski, K.M., 2006. An expanded model of the factors affecting the acceptance and effectiveness of electronic human resource management systems. Human Resource Management Review, 19(2), pp.134-143.

Subramaniam, M. \& Youndt, M.A., 2005. The Influence of Intellectual Capital On The Types Of Innovation Capabilities. Academy of Management Journal, 48(3), pp.450-463. 
Wright, P.M., Coff, R. and Moliterno, T.P. (2014) Strategic human capital: crossing the great divide, Journal of Management, 40(2): pp. 353-70.

Youndt, M., Subramaniam, M. \& Snell, S., 2004. Intellectual capital profiles: An examination of investments and returns. Journal of Management Studies, 41(2), pp.335-361.

Youndt, M. A., \& Snell, S. A. (2004). Human resource configurations, intellectual capital, and organizational performance. Journal of Managerial Issues, 16(3), pp. 337-360. 
Table 1. Descriptive statistics and correlations

\begin{tabular}{|c|c|c|c|c|c|c|c|c|c|c|c|}
\hline & Mean & St. Dev. & 1. & 2. & 3. & 4. & 5. & 6. & 7. & 8. & 9. \\
\hline 1. Organizational performance & 3.68 & .63 & & & & & & & & & \\
\hline 2. Performance Pay & 5.43 & 2.87 & $.309 * *$ & & & & & & & & \\
\hline 3. e-HRM & 4.29 & 1.62 & $.230 * *$ & $.469 * *$ & & & & & & & \\
\hline 4. Intellectual capital & 2.31 & .57 & $.271 * *$ & $.279 * *$ & $.283 * *$ & & & & & & \\
\hline 5. Org. Size & 2.22 & 1.22 & .065 & .108 & $.351 * *$ & $.234 * *$ & & & & & \\
\hline 6. Org. age & 69.08 & 88.95 & -.128 & $-.176^{*}$ & .028 & .108 & $.195 *$ & & & & \\
\hline 7. Manufacturing & .34 & .47 & -.010 & .055 & .057 & $.205^{* *}$ & -.037 & -.006 & & & \\
\hline 8. Services & .42 & .49 & -.137 & -.127 & $-.189 *$ & $-.199 * *$ & .016 & -.146 & $-.606^{* *}$ & & \\
\hline 9. Market trend & 2.88 & .80 & $.297 * *$ & .124 & .098 & .079 & -.002 & -.065 & -.020 & -.066 & \\
\hline 10. Higher education & 3.50 & 1.13 & $.242 * *$ & $.187 *$ & $.209 * *$ & $.174 *$ & .074 & .042 & $-.259 * *$ & -.024 & $.161 *$ \\
\hline
\end{tabular}


Table 2. Hierarchical multiple regression results for organizational performance

\begin{tabular}{|c|c|c|c|c|c|c|c|c|}
\hline & \multicolumn{2}{|c|}{ Model 1} & \multicolumn{2}{|c|}{ Model 2} & \multicolumn{2}{|c|}{ Model 3} & \multicolumn{2}{|c|}{ Model 4} \\
\hline & $B$ & s.e. & $B$ & s.e. & $B$ & s.e. & $B$ & s.e. \\
\hline Org. size &, $15^{\dagger}$ & ,08 & 05 & ,088 & ,05 & ,09 & ,03 &, 09 \\
\hline Org. age &,$- 37 * * *$ & 10 &,$- 32 * *$ & 100 &,$- 31 * *$ & 10 &,$- 30 * *$ & 10 \\
\hline Industry $^{\mathrm{a}}$ & & & & & & & & \\
\hline Manuf. &, 06 & 23 &,- 03 & ,221 &,- 04 & ,22 &,- 01 & ,22 \\
\hline Services &,- 19 & ,23 &,- 19 & ,221 &,- 18 & 22 &,- 191 &, 21 \\
\hline Market trend &, $34 * *$ &, 10 &, $30 * *$ & 093 &, $30 * *$ & 10 &, $29 * *$ & 09 \\
\hline Higher education &, 14 & ,07 &, 06 & 074 &, 08 &, 07 &, 07 & 07 \\
\hline Performance Pay & & &, $07^{\dagger}$ & ,034 & $08^{*}$ &, 03 &, $09^{* *}$ &, 04 \\
\hline e-HRM & & & 06 & ,066 &, 03 & ,07 &, 04 & ,07 \\
\hline Intellectual capital & & & ,26 & 162 &, $33 *$ &, 17 &, $57 * *$ &, 19 \\
\hline $\begin{array}{l}\text { Performance pay*e- } \\
\text { HRM }\end{array}$ & & & & &,- 01 &, 02 &,- 01 & ,02 \\
\hline $\begin{array}{l}\text { Performance } \\
\text { pay*Intellectual capi- } \\
\text { tal }\end{array}$ & & & & &,- 02 &, 07 &,- 02 &, 07 \\
\hline $\begin{array}{l}\text { e-HRM*Intellectual } \\
\text { capital }\end{array}$ & & & & &,- 17 &, 11 &,$- 25^{*}$ &, 11 \\
\hline $\begin{array}{l}\text { Performance pay*e- } \\
\text { HRM*Intellectual } \\
\text { capital }\end{array}$ & & & & & & &,$- 09 *$ &, 04 \\
\hline Adj. $R^{2}$ & .25 & & .31 & & .32 & & .35 & \\
\hline F change & $7.1 * * *$ & & $6.4 * * *$ & & $5.4 * * *$ & & $5.6 * * *$ & \\
\hline
\end{tabular}

Note. $\dagger \mathrm{p}<.10, * \mathrm{p}<.05, * * \mathrm{p}<.01, * * *<.001$. Ref. category: a) Advanced services 
Fig. 1. Interaction between Intellectual capital and e-HRM on organizational performance

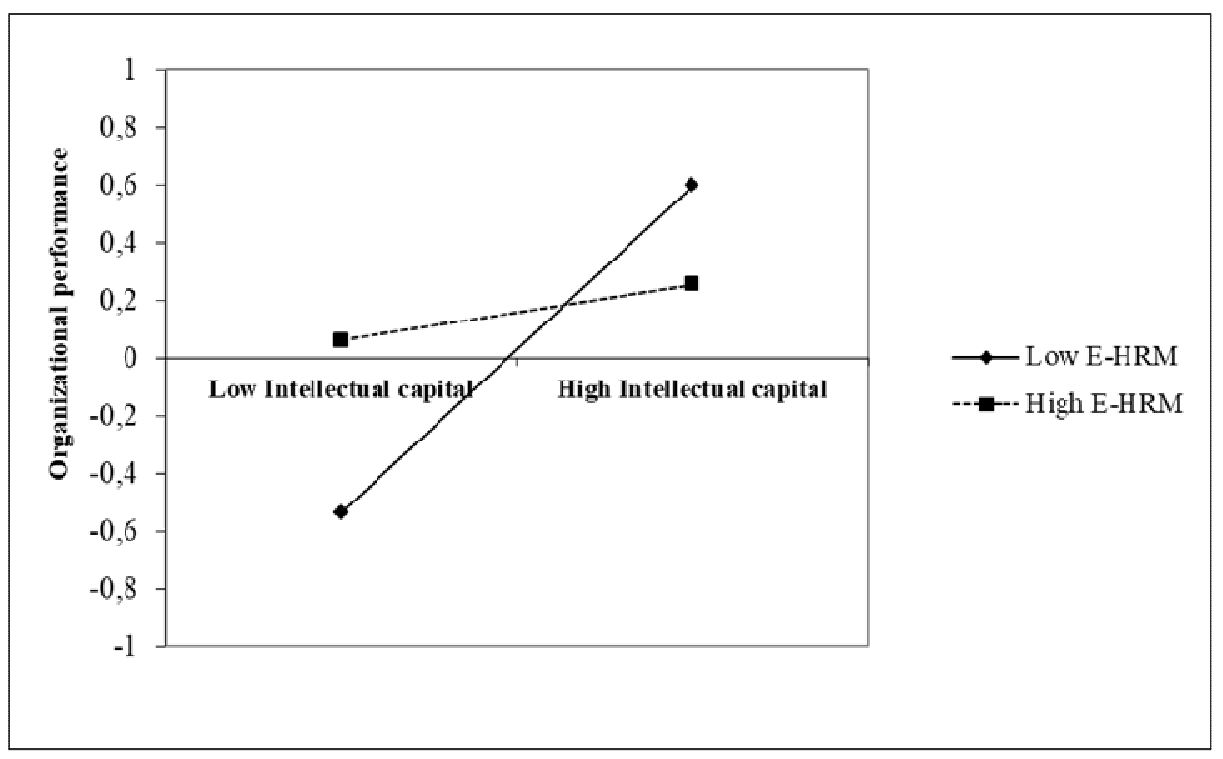


Fig. 2. Relationship between performance pay and organizational performance for different levels of e-HRM and intellectual capital

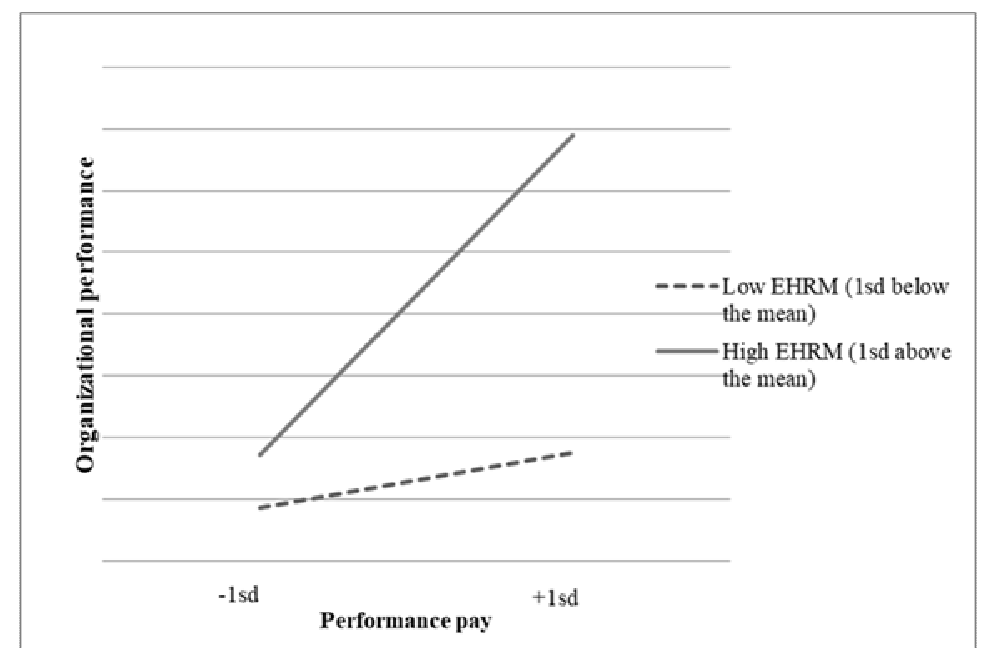

a) Low intellectual capital

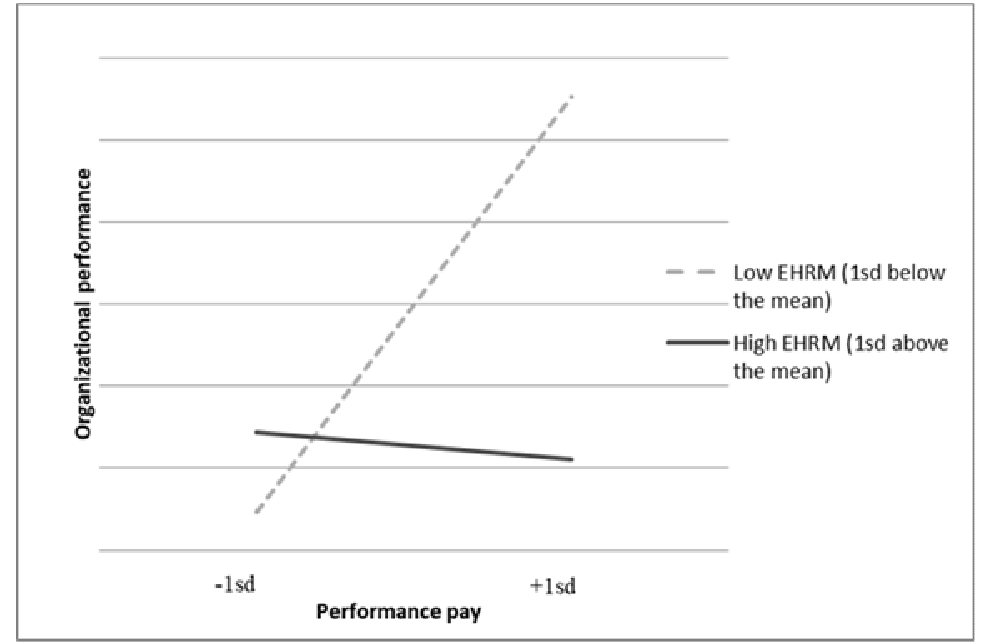

b) High intellectual capital 